Saudi Journal of Medicine

Abbreviated Key Title: Saudi J Med ISSN 2518-3389 (Print) |ISSN 2518-3397 (Online)

\title{
Effectiveness of Streetplay Based Learning over Regular Classroom Learning in Students of MBBS I ii in the Department of Tb and Chest
} Dr. Krishna Prasad R ${ }^{1}$, Dr. Shreesha Khandige ${ }^{2 *}$

${ }^{1}$ Associate Professor, Department of TB and Chest (Respiratory Medicine), Kanachur Institute of Medical Sciences, Deralakatte, Mangalore, India ${ }^{2}$ Professor and HOD, Department of Pathology, Kanachur Institute of Medical Sciences, Deralakatte, Mangalore, India

DOI: $10.36348 /$ sjm.2020.v05i02.007 $\quad$ | Received: 02.02.2020 | Accepted: 09.02.2020 | Published: 14.02 .2020

*Corresponding author: Dr Shreesha Khandige

\section{Abstract}

The street play based learning is becoming more popular to support learning process of students in professional colleges by asking students to understand the basis of clinics and also the attitude and behavioural learning using a street play which the students will display to other students. Bed side clinics are the gold standard but as the number of colleges is increasing the number of patients is slowly decreasing. It is practically impossible to show all the cases to the learning students. But there is a way and it is in this way that the professional actors or the doctors themselves who has knowledge of the disease can enact and thus teach the students. This study puts in a sincere effort to find the answer of which method is better.

Keywords: Integrated learning, Class room teaching, MCQ.

Copyright @ 2020: This is an open-access article distributed under the terms of the Creative Commons Attribution license which permits unrestricted use, distribution, and reproduction in any medium for non-commercial use (NonCommercial, or CC-BY-NC) provided the original author and source are credited.

\section{INTRODUCTION}

The street play based learning is becoming more popular to support learning process of students in professional colleges by asking students to understand the basis of clinics and also the attitude and behavioural learning using a street play which the students will display to other students. Bed side clinics are the gold standard but as the number of colleges is increasing the number of patients is slowly decreasing. It is practically impossible to show all the cases to the learning students. But there is a way and it is in this way that the professional actors or the doctors themselves who has knowledge of the disease can enact and thus teach the students. This study puts in a sincere effort to find the answer of which method is better.

This study puts in a sincere effort to find the answer of which method is better ${ }^{1}$. One of the main reasons is the compartmentalised manner in which they are taught by each clinical department at different time, without any knowledge of what is taught by the other departments [1, 2]. Classroom time is spent in discussion, clarification, exercises, or other learning activities to enhance application of knowledge [3]. This method is implemented in the Medicine, Dental and other Allied courses [4, 5]. Some cases they recorded that the convention class room was better, in other cases the opposite was quoted as better and there are some studies where they have reported a mixed perception and satisfaction levels. In some studies they even reported that the supplementary learning teaching was better perceived which did not reflect in the actual performance of the students $[5,6]$. This study puts in a sincere effort to find the answer of which method is better $[8,9]$.

\section{AIMS AND OBJECTIVES}

1. To compare the effectiveness of the Strret play Based learning and regular classroom learning.

\section{MATERIALS AND METHODS}

Settings-Department of Respiratory Medicine in collobaration with the Department of Pathology, Kanachur Institute of Medical Sciences

The study was done on 100 students who attended classes in the Department of Respiratory Medicine from Jan 2018 to July 2018.

Design - Educational intervention will be done by street play based on teaching in one month duration and performance of the students is compared for two methods along with the perception.

Subject - Students of MBBS Phase III will be enrolled into the study after obtaining informed consent excluding the students who don't give consent for the study. 
Sample size - 100 students of MBBS phase III who are willing to participate

Methodology: They will be equally divided into two groups by lottery method. One batch will go for traditional lecture classes and the other will be taught using street play based teaching. After every class the MCQ test of the students will be taken. The means of the scores will be noted. The mean of all the scores after all the three sessions will be calculated and reported.
Sampling technique - All the students of MBBS phase IV who are willing to participate are considered for both the methods of teaching to avoid the bias of the students for the topics.

Data collection - Pre-test and post -test scores are used to assess the students after answering MCQs.

Data analysis - Unpaired and Paired T Test.

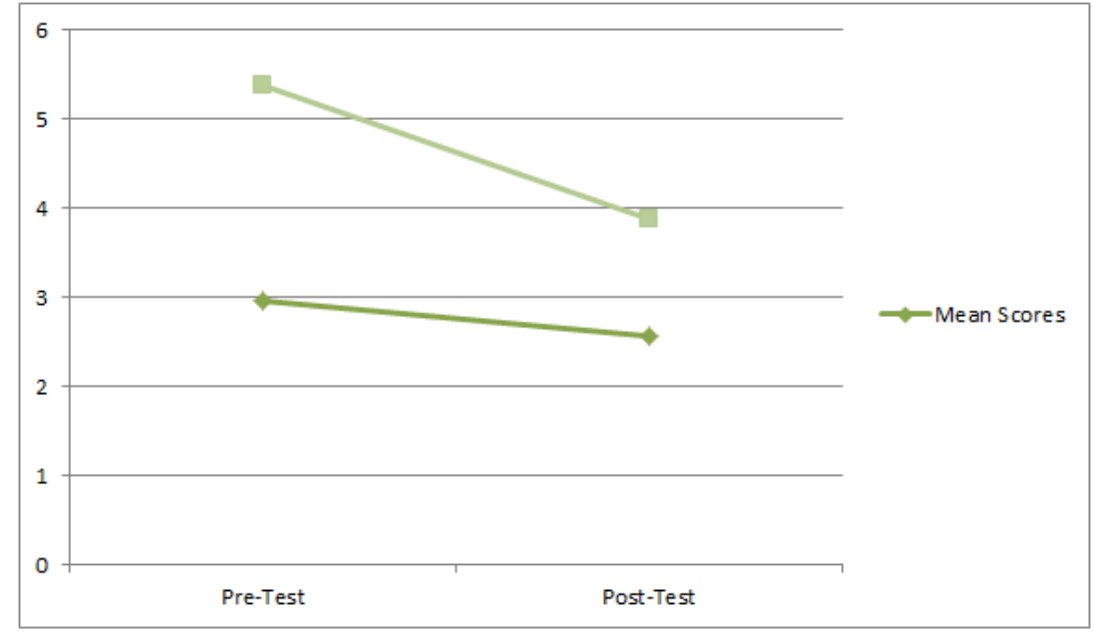

P VALUE NOT Significant

Graph-1: Pre and Post Test scores between the two groups

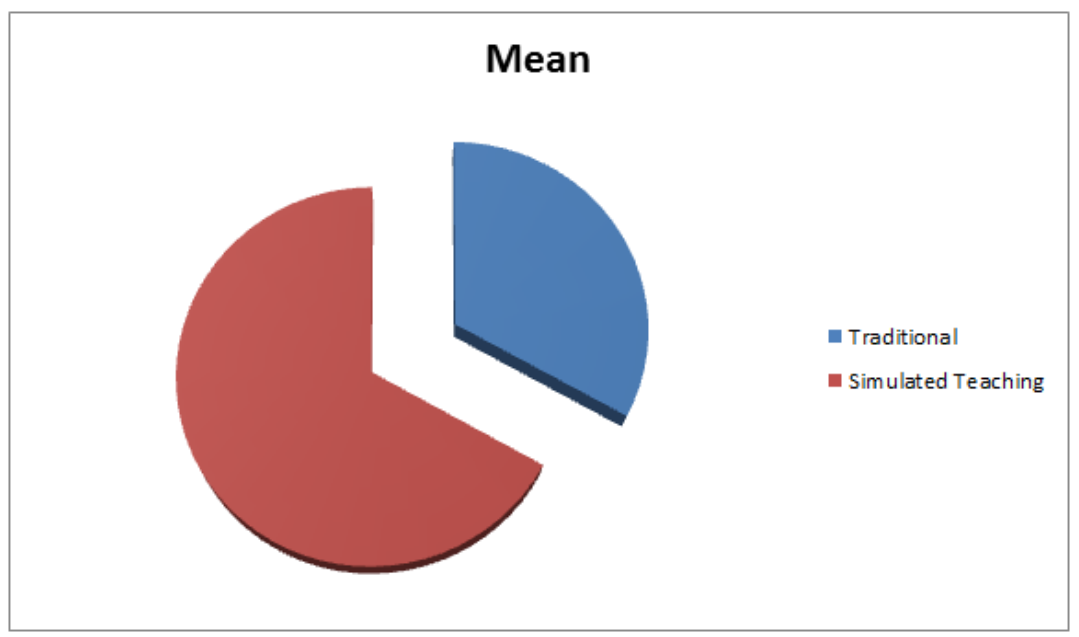

P VALUE $<0.001$ HIghly Significant

Graph-2: Independent $t$ test to compare post-test scores between the two groups immediately after the intervention

\section{DISCUSSION}

A great deal of research has concluded that play-based learning is genuinely and positively impactful on student learning and development. Kathryn Hirsh-Pasek, a well-known child development expert in the Department of Psychology at Temple University and a Senior Fellow at the Brookings Institution, argues that humans learn best when at least one of these four pillars is present:
1. Individuals take an active role in the learning environment

2. They are engaged

3. Information is meaningful

4. Learners interact in a social context

This means that children learn well when they are mentally active, engaged, social, and can make meaningful connections to their lives, which are all characteristics of play. 
Another study found that "in addition to improving play skills and narrative language ability," a play-based curriculum also had "a positive influence on the acquisition of grammar." Neuroscientists have found that play activates the brain in meaningful ways that rote memorization, testing, worksheets, and traditional classroom techniques do not.

"When you are engaging in play, which in and of itself is a symbolic metaphor in its truest form, whole parts of your brain are engaged, developing crucial connections that lead to a positive development of the child,". Play-based learning is real learning. The assumption that plays is a frivolous use of classroom time and in opposition to rigorous instruction demeans its value and its vast potential. "Many people, including some educators, believe that we need to choose between play-based learning opportunities and rigorous academic standards when integrating the two is very possible," says Concordia University-Portland adjunct professor, Angie Stratton, M.A.Ed. "For example, a kitchen/cooking center could contain a water table as well as measuring cups, dishes and 'pretend' food. Paper and pencils/crayons/markers, etc., can be used to write recipes, make lists, and create advertisements for a new restaurant. The creative possibilities are endless. Not only does this play-based learning center address language arts standards, but it also touches upon speaking and listening standards as well. Intentionally structuring a play-based learning opportunity to encourage creative play as well as include materials that emphasize a developmentally appropriate learning standard is certainly a high-leverage practice." Purposeful play

\section{CONCLUSION}

The Street Play Based Learning teaching room teaching is perhaps the clear winner.

\section{REFERENCES}

1. Morton, D.A., Colbert-Getz, J. (2016). Measuring the impact of the Integration: The importance of categorizing an assessment by bloom's taxonomy. Anat. Sci. Educ. 10, 170-175.

2. Presti, C.R. (2016). The Learning Approach in Nursing Education: A Literature Review. J. Nurs. Educ, 55, 252-257.

3. Chen, F., Lui, A.M., Martinelli, S.M. (2017). A systematic review of the effectiveness of Alternate Methods of learning teaching rooms in medical education. Med. Educ. 51, 585-597.

4. Betihavas, V., Bridgman, H., Kornhaber, R., Cross, M. (2016). The evidence for: A systematic review of the supplementary learning teaching room in nursing education. Nurse Educ. Today, $38,15-21$.

5. McLaughlin, J.E., Roth, M.T., Glatt, D.M., Gharkholonarehe, N., Davidson, C.A., Griffin, L.M., Esserman, D.A., Mumper, R.J. (2014). The Case based simulated learning teachingroom: a course redesign to foster learning and engagement in a health professions school. Acad Med, 89:236243.

6. King, A. (1993). From sage on the stage to guide on the side. Coll Teach. 41:30-5.

7. McCabe, C., Smith, M. G., \& Ferreri, S. P. (2017). Comparison of flipped model to traditional classroom learning in a professional pharmacy course. Education Sciences, 7(3), 73.

8. Peggy Wallace. "Following the Threads of an Innovation: The History of Standardized Patients in Medical Education". Archived from the original on December 28, 2008. Retrieved 200809-28.

9. Biography of Dr. Paula, L. S. (2003). Standardized/Simulated Patients in Medical Education Archived June 23, at the Wayback Machine. 